\title{
Factors Limiting the Production and Productivity of Canola in Western Cape, South Africa
}

\author{
Elliot Negros Madonsela* \\ Department of Crop Science, Faculty of Science, Tshwane University of Technology, South Africa
}

*Corresponding Author: Elliot Negros Madonsela, Department of Crop Science, Faculty of Science, Tshwane University of Technology, South Africa.

Received: July 30, 2019; Published: August 08, 2019

DOI: 10.31080/ASAG.2019.03.0606

Canola is a specific type of edible rape seed that was bread in the 1970 s and developed, it is said to have $40 \%$ oil in each seed. In this study Canola production will be looked at to understand the factors that influence its growth in any way. Then the major focus will be on limiting factors for the crop and if there are any measures to counter or control.

Canola is said to be a term for a specially breed rapeseed edible crop, which means "can" for Canada and "ola" means oil. The name was registered by the Western Canadian Oilseed Crushers Association [1]. Canola is a cool season crop and according to Gruber, Emrich and Claupein [2] it has been known to show dormancy traits in seeds. This crop is an oilseed rape namely Brassica genus, Brassiceae tribe belonging to the crucifer family. This genus is said to have 37 different species that are edible roots, leaves, stems, buds, flowers and seed. There is a wide variation in flower shape and colour from yellow, white to violet and the colour of mature seeds from yellow to black [3]. There has been record of other varieties which differ in maturity periods and yield majorly.

The growth requirements of the crop, planting dates will be looked at to identify whether a surplus or lack serve as a limiting factor for production. Crop requirements such as fertilization, irrigation, temperature, light, weather and soil requirements. The location of the farm or where the crop is planted also plays a role in the production of the crop. In this case the area of case study is the Western Cape. Since canola is a temperate crop it is mostly planted in the winter rainfall areas of the Western Cape. Distribution of the crop in the Western Cape highly depends on growing degree days, photothermal units and seasonal water supply, according to Hardy and Wallace [4] approximately 800000 ha of arable land is suited to rainfeed winter ceraeal production systems, $37 \%$ of which has high production potential, $56 \%$ has intermediate potential the rest of which productivity is debatable. Other Capes have also tried planting the crop under irrigation for different varieties. There are two main canola varieties, the Argentine species Brassica napus which takes 95 to harvest and the Polish species Brassica rapa that takes 80 days to harvest. The Argentine variety has more oil content than the Polish variety and is taller increasing its yield potential [1].

The economic importance of canola is its high production potential, it is known to have $40 \%$ oil content in the seeds. It has a high protein content which makes the shell crushings a good feed for animals and doesn't have saturated fats, which is beneficial for humans as it lowers cholesterol. According Mirco Nolte [5] Canola costs less to produce than sunflower and requires less space/land to produce the same amount of oil as sunflower. With understanding of these dynamics canola may well be the way to conservational agriculture. Potentially canola could be used for the manufacturing and processing of biodiesel which will impact the environment well as biodiesel production has less toxic gasses going into the atmosphere. The objective in this study was to conduct research on the factors that limit the production of canola, these factors could entirely impair production or cause a challenge which was solved by whatever means. The research was done by methods of literature review as it is what's required at this level of qualification. Scientific texts that had undergone peer review were used to validate the information written here.

Scientific literature was used to understand the requirements of the crop to better make a case for its limiting factors, for instance when looking at soil the structure, texture, moisture content, oxygen availability, drainage and chemical composition had to be investigated to know the optimal soil conditions preferred for production. Canola is suited for clay-loam soils that don not crust, if grown on soils with poor internal drainage then good surface drainage is vital as the crop cannot tolerate waterlogged conditions [1]. This background information was to know what implements where used in making the soil conditions suitable and if that could 
be a limiting factor. Irrigation was also considered whether production was rain fed of irrigated by means, what type of irrigation would be best and irrigation strategy to best suit the crop. Weather was reviewed as canola is a temperate crop it need cool temperatures and a lot of moisture, hence the limited distribution in the Western Cape. According to Phil Thomas [6] to reach just 160kg/ ha $25 \mathrm{~mm}$ of water must be available and this is dependent on the plant density. Lower plant density handle drought better than a high plant density.

High densities also pose a great threat when it comes to disease and epidemics. According Petrie, Mortensen and Dueck [7] canola is highly susceptible to the blackleg virus caused by the leptosphaeria maculans pathogen but this majorly affects the Brassica napus and Brassica campestris. High population density can enhance the spread of disease whether it be virus, fungal or bacterial. According to Guo, Fernando and Entz [8] (quoted Fernando et al. 2003) most serious diseases of canola have started to appear in new areas. So investigation was done to know what conditions favour pathogens and how to control them. During literature review it was realized that rotation is essential for the production of canola. According to Kutcher and Brandt (2008) rotation can be used as a tool for pest, disease and moisture control especially when rotated with other types and not cereals because it means less pest and pathogen susceptibility and readily available moisture if the ground is on recharge. A lot of other production components were further explained in the body of this seminar and concluding factors that limit production in the Western Cape South Africa were stated and outlined.

\section{Bibliography}

1. Berglund DR., et al. "Canola Production". Fargo: North Dakota (2007).

2. Gruber S., et al. "Classification of canola (Brassica napus) winter cultivars by secondary dormancy". Germany: Stuttgart 89.4 (2009): 613-619.

3. Rakow G. "Biotechnology in Agriculture and Forestry". Chapter 1. Edited by E.C. Pua and C.J. Douglas. Springer-Verlag Berlin Heidelberg 54 (2004).

4. V Hardy MB and Wallace MG. Determining area of arable land suited to canola production in the Western Cape 1 (2013).

5. Mirco N. "Commercial Biodiesel Production in South Africa: A Preliminary Economic Feasibility Study”. Stellenbosch (2007).
6. Thomas P. South Africa Canola Production. Lacombe: Canada (2012).

7. Petrie GA., et al. "Canadian plant disease survey". 65 (1985): 35-41.

8. Guo XW., et al. "Effects of crop rotation and tillage on blackleg disease of canola”. Winnipeg: Canada (2005).

Volume 3 Issue 9 Sepetember 2019

(C) All rights are reserved by Elliot Negros Madonsela. 